I I UC STUDI ES

ISSN 1813-7733

Vol. - 3, December 2006 (p 93-104)

\title{
Sayyid Mawdudi's Contribution towards Islamic Revivalism
}

\author{
Dr. Thameem Ushama* \\ Dr. Noor Mohammad Osmani* ${ }^{*}$
}

\section{Introduction}

The world of the 20th Century witnessed some great scholars who had contributed extensively for the promotion of Islam and to establish it as a complete code of life. Mawdudi had secured a respectable place in it. He had shown in practical terms how Islam could be pressed into the service of the modern people and their day-to-day problems.

Mawdudi started his mission at a time when all Muslim countries were under direct or indirect subjugation of the Western colonial rulers. The call he made in 1932 as a cry in wilderness was well received by the like-minded Muslims of the world.

He founded Jama at-i-Islami in 1941 with the sole objective of Iqamat-i-din, or establishing Islam in every aspect of life. The branches of Jama at-i-Islami are now not confined in Pakistan alone, they are spread throughout the world. Most of the Islamic organizations regard him as a key figure of Islamic movement and benefit from his literature.

Mawdudi was a man of versatile ingenuity. He showed in practical terms how Islam could be used today to solve the problems of Muslims in modern ages. It was his literature that provided the bases for Islamic political system, economic system, cultural system, social system and so on. Many of his contemporaries were doubtful that Islam could also provide constitutional guidelines. Mawdudi, not only highlighted the constitutional principles of the Qur'an, but also fought to establish it in Pakistan. The people came to realize that Islam is not the name of some symbolic festivals, but it is a complete way of life.

This comprehension of Islam as a complete code of life, and straightforward expression earned him the hostility of many; while many others appreciated him and enthusiastically followed him. Some even accused him of claiming the position of "Mujaddid", "Mahdi" or establishing a new sect of "Mawdudism". ${ }^{1}$ He passed away without claiming any of such positions for him, or trying to establish a new sect. His life was rather dedicated to unite various sects under the banner of the Qur'an and Sunnah.

Mawdudi's pen was prolific and forceful. His major contribution lies in presenting an up-to-date Tafsir, Tafhim al-Qur'an, for the modern Muslims. Its chief characteristic lies in presenting the meaning and message of the Qur'an in a language and style that penetrates the hearts and minds of the men and women of today and shows the

* Associate Professor, Department of Usuluddin and Comparative Religion, International Islamic University Malaysia.

** Assistant Professor, Department of Qur'an and Sunnah Studies, International Islamic University Malaysia. 


\section{IIUC Studies, Vol. 3}

relevance of the Qur'an to their everyday problems, both on the individual and societal planes. He presented the Qur'an as a book of guidance for human life and as a guidebook for the movement to implement and enforce that guidance in human life. $^{2}$

His life was like an open book. He was a specimen of what a man in general and a true believer in particular should be. Masudul Hassan, a contemporary of Mawdudi, describes him in the following terms:

With his saint-like appearance, magnetic personality, sublimity of character, transparency of sincerity, nobility of demeanor, affability of manners, geniality of temperament, deep sense of humor, scintillating wit and spontaneity, depth of understanding, firmness of purpose, breadth of vision, dedication to cause, detachment and selflessness, unbounded courage, unwavering faith, unprecedented patience, uncommon wisdom, and steel- like determination, the Maulana was an ideal specimen of what a man in general and a Muslim in particular should be. He was an embodiment of Islamic virtues. He lived and died for Islam. His place is among the great Muslims of all times. ${ }^{3}$

\section{Mawdudi's Life: A Brief Account}

Born on 25th September, 1903 at Aurangabad, India, ${ }^{4}$ Mawdudi received his early education at home. At the age of eight, he was admitted into a local school, and in 1916, was admitted into Darul-'Ulum College of Hyderabad for his matriculation studies. Mawdudi could hardly pass six months that his father suffered severe attack of paralysis and had to postpone studies attending his ailing father for about two years.

Since then, Mawdudi had to struggle in life. His formal education came to a standstill. He suffered serious financial difficulties. He joined elder brother Abul Khair in the editorial board of Madina, Delhi at the age of fifteen, and later they ran a weekly paper Taj. In 1921, his financial condition improved, and resumed his studies that were postponed earlier. He studied Tafsir, Hadith, Fiqh, Usul, English and many other subjects from the famous scholars of that time. He used to attend some of his teachers even before Fajr prayers as scheduled by the teachers. In 1925-1928, he editored the daily Al-Jam 'iyyat single handedly, which raised his confidence about his abilities. ${ }^{6}$ In 1928, he wrote his first magnum opus, a noble masterpiece on the subject of Islamic War, namely, Al-Jihad fi al-Islam, a book, which though written by Mawdudi in his 20s, acclaimed by great scholars like Iqbal. ${ }^{7}$

In 1932, he decided to run his own journal, namely Tarjumanul Qur'an ${ }^{8}$ as a mouthpiece for Islamic revivalism that he was cherishing since long. He invited the Muslims of the world and especially those of India to rise with the banner of Islam as did the earlier companions of the Prophet.

It was through Tarjumanul Qur'an that he invited people, who were determined to dedicate their life for the establishment and promotion of Islam in every aspect of life, to participate in the formation of Jama at-i-Islami. In 1941, 26th August, Jamaati-Islami was established with the active participation of 75 foundig members.' Mawdudi raised his voice to establish a separate land for Islam and Muslims, and after independence in 1947 demanded immediate implementation of Islam in the 


\section{Sayyid Mawdudi's Contribution Towards Islamic Revivalism}

newly born state of Pakistan. But the ruling authority did not listen to the demands of Mawdudi and Islamic people of the country.

In 1953, 11th May, he was awarded death sentence by the Marshal court of Pakistan because of writing a pamphlet on Qadiyanism. ${ }^{10}$ The Muslims protested world-wide to lift the sentence on Mawdudi, and urged the government to send him to other countries if his presence was not desired in Pakistan. Mawdudi was asked to appeal for Mercy, but he rejected to submit Mercy petition to the government. Finally it was commuted to life imprisonment. Later the High Court set aside the life imprisonment and freed Mawdudi respectfully from the term of imprisonment. ${ }^{11}$

Mawdudi led the Jama'at-i-Islami with his effective leadership, and contributed many books and articles on fundamental aspects of Islam and its contemporary application in various fields. The most important writing was his widely known Tafsir, Tafhim-ul-Qur'an, which took about 30 years to complete. Mawdudi suffered illness several times and in 1972 he appealed to the highest council of Jama at-iIslami to relieve him from the post of Amir-i-Jama at, which was later approved by the Members of the Jama at. ${ }^{12}$ He was relieved and concentrated fully to complete Tafsir, which he did in the same year. A few years later, he fell seriously ill, and was taken to USA by his son who was working there in a hospital as a medical Doctor. He died on September 22, 1979 in Buffalo, USA. ${ }^{13}$ He was buried at his house in Lahore where he used to hold daily afternoon sessions with the people and used to answer all kind of questions.

\section{Presentation of Islam}

Mawdudi presented Islam in pristine, pure, plain and every day language that appealed the mind and heart of the people without engaging in philosophical jargons and abstract ideas. The style he adopted was so forceful, rational and impressive that it captivates the readers. He drew examples from day-to-day life, which naturally convince the people to the viewpoint of Mawdudi.

He did not produce a new brand of Islam. He removed false imaginary obstacles between the Creator and mankind. He brought people close to their Creator. He presented a pure and holistic image of Islam - free from all kind of distortions, Jahily images and superstitious beliefs.

Sayyid Mawdudi presented Islam as a complete code of life. It is a way of life, a culture and civilization that captivates peoples' hearts and convinces their minds easily. It encompasses all aspects of human life. He systematically presented Islamic political system, economic system, cultural system, social system, ethical system and so on. ${ }^{14} \mathrm{He}$ uprooted the confusion that Islam was but the name of some scattered teachings. He underlined the fundamental principles for most of these aspects based on the Qur'an and Sunnah. ${ }^{15}$ He urged that a Believer in Islam should accept it as a whole. Accepting some part of Islam and rejecting some others is a sheer hypocrisy and perversity. Allah says in the Qur'an:

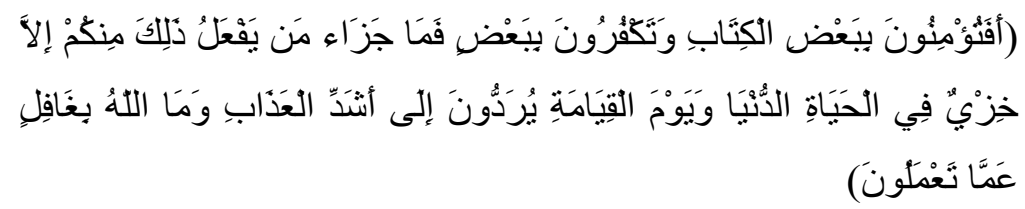

"Then is it only a part of the Book that ye believe in, and do ye 


\section{IIUC Studies, Vol. 3}

reject the rest? But what is the reward for those among you who behave like this but disgrace in this life?- and on the Day of Judgment they shall be consigned to the most grievous penalty. For Allah is not unmindful of what ye do."16

He was not a blind follower of Islam. He was against all preconceived beliefs without critical evaluation. He underwent a brief period of confusion and doubt after approaching and reading freely the Western philosophies and ideologies. His inner faith was shaken and conviction in Islam was almost shattered. ${ }^{17}$ Then he returned to the Qur'an. There he found the answers of all questions and solution to all problems. He energized his fullest efforts towards propagating Islam and to clear up all confusions that have been labeled against it. His heart was convinced of its truthfulness and supremacy to all other religions and ideologies. It was only then that he accepted Islam in the true sense after comprehending it perfectly.

\section{A LUCID image of Islamic State}

He presented a comprehensive and viable image of Islamic state. It was alien to the modern men that Islam has a political system and that a modern state could efficiently be run under the Islamic principles. A famous lawyer, A. K. Brohi of Pakistan posed a challenge that if anyone could show to him that the Qur'an has a Constitution, would be rewarded. Sayyid Mawdudi wrote his famous pamphlet on 'The Fundamental Bases of Islamic Constitution', and in a subsequent lecture at the Karachi Bar Association, he presented a detailed lecture on 'Codification of Islamic Law and its application in Pakistan'. A. K. Brohi was highly impressed by the encyclopedic knowledge and pleasing personality of Sayyid Mawdudi that he became a lifetime admirer of the latter. ${ }^{18}$ Mawdudi presented systematically the theory of Islamic state in a series of lectures and pamphlets. They are compiled in his Islamic Law and Constitution.

According to Mawdudi, Islamic state is based on three fundamental principles: Tawhid, Risalah and Khilafah. Tawhid means that the sovereignty vests in Allah alone, and that His commandments are the basic law. Risalah stands for the supremacy of the Shari ah, i.e. the Qur'an and the Sunnah. Khilafah stands for the vicegerency of man. In Western democracy, sovereignty vests in the people; whereas in Islam, sovereignty vests in God. ${ }^{19}$

The aim of an Islamic state is the establishment of virtue and the eradication of evil. The Government of an Islamic state is to be the responsibility of an Amir, who must be an embodiment of the Islamic virtues. He is to be advised by an advisory council. Legislation has to be undertaken within the limits set down by the Shari'ah. In an Islamic state the judiciary must be independent. An Islamic state stands for absolute justice and equality among people. Equality has to be enforced in all spheres: social, economic, and political. Every citizen will have the right to criticize the Government. Non-Muslim citizen have to be guaranteed protection, and they must enjoy full freedom of conscience and belief. ${ }^{20}$

\section{Islamic Reformer}

Under the influence of Western thought the Muslims were driven away from Islam. The Muslims had three different reactions to the Western culture and thought. The first reaction was that of total subservience to the Western thought, as done by Mustafa Kamal in Turkey. The second reaction was the manifestation of defeatist mentality and having an apologetic approach to the West. Islam was presented in a 


\section{Sayyid Mawdudi's Contribution Towards Islamic Revivalism}

way that it conforms to the Western thought, culture and modern science. That was the approach of Sir Sayyid Ahmad Khan and his followers. The third reaction was that of the fundamentalists, who rejected the Western thought and culture outright without having a critical evaluation. ${ }^{21}$

In this crisis of ideological conflict, Sayyid Mawdudi adopted a new line of action. He categorically explained that Islamic culture and thought is much superior to the rest of cultures. It is supreme to the West and its ideologies. Muslims should not surrender to the Western thought. He mentioned to the defeatists and apologetics that Islam encouraged Tajdid and not Tajaddud. Tajdid was the re-interpretation of Islam in the light of modern circumstances without sacrificing its ideals and principles; whereas Tajaddud implied innovation, and the manufacture of new brands of Islam in conformity with western thought. According to Mawdudi, Islam was something to be rediscovered; it was not something to be invented; for it was already there, and had held the field for the last fourteen hundred years. He also criticized the approach of the traditionalists, who blindly rejected all what is western or invented by the West. According to him, Islam is society in motion and if any attempt is made to arrest the process of motion that would be damaging to the cause of Islam. He observed that the need of the hour was to re-think Islam in modern context and make Islam relevant to the special needs of today. ${ }^{22}$

Through his writings, Mawdudi explained how reformation could be brought about in various fields, political, social, economic, cultural and so on. He shaped the ideas of people into Islamic mold. He insisted the government of Pakistan to establish Islam in its systems as the land of Pakistan was attained under the name of Islam. He mobilized people's attention towards implementing Islam in all aspects of human life. A. K. Brohi explains the impact of Mawdudi on introducing an Islamic order in the history of Pakistan and says:

"Any impartial student of Pakistan history will have to admit that the one person responsible for mobilizing public opinion in favor of establishing a State which was to reflect the Muslim ideal was none other than Mawlana Mawdudi.... His greatest achievement is that he carried on his crusade, both as a scholar and reformer, not in a cosy and comfortable academic forum, but in the arena of the noisy streets of Pakistan." 23

\section{Superiority of Islamic Culture}

During the 18th and 19th centuries, Islam and Muslims were harshly condemned by many orientalists and anti-Islamic groups. The Islamic Culture was made synonymous and equal to anti-human culture, barbarism and terrorism throughout the world. Backwardness, underdevelopment and anti-progress were equalized with Islam. It was claimed that Islam barred women from participating in the development of nation. Islam was accused of being advanced by the dint of swords. As a result, the modern educated Muslims had the illusion that their culture is inferior to that of the West.

Mawdudi used his prolific writings to remove those confusions and to establish the fact that Islam was and is always superior to all cultures of the world. He wrote Al-Jihad fi alIslam [The Concept of War in Islam] to condemn the claim that Islam supports terrorism and was spread by sword.24 Though it was written in his 20 s, it remained as a magnum opus on the subject of the concept of War in Islam. The impact of this book was so great 


\section{IIUC Studies, Vol. 3}

that 'Allamah Iqbal, the poet philosopher, acclaimed the book in superlative term, and urged Muslims to read it. The most important feature of this book is that it presents the Islamic concept of war plainly and forcefully. It did not adopt apologetic stance as many modern Muslim scholars did. Mawdudi did not try to mince matters. The reader could easily notice the superiority of Islamic concept of war over the rest of cultures. He also wrote his Purdah [Veil]25 to expose the real status of Women in Islam comparing their status throughout the cultures of the West and the East. He proved successfully that the status of women in Islam as has been prescribed by the Qur'an and Sunnah is the supreme, noble and is in perfect harmony with the inherent nature of women.26

\section{Dispelling Multi-Faceted Confusion}

Many people attacked on Islam and its tenets, Muslims and non-Muslims alike. Many Western Orientalists tried to deform Islam and present an adulterated image to the world, so that no one would like to come closer to Islam, and that the Muslims feel shameful for being attached to it.

Many modern Muslim writers were influenced by them and tried to innovate a modern Islam based on their personal desires. Their main target was to make Islam acceptable to the modern world, i.e. to "civilize" (!) Islam; hence rejecting many of its fundamental teachings. Some of them disregarded the Hadith of the Prophet; and that the Qur'an is a complete book of Allah. The Muslims need no additional guidance apart from the Qur'an. Others declared Jihad forbidden in the current age. It was, to them, a temporary need of Islam in the early age, which is irrelevant in today's global world. Some validated riba in the banking transactions declaring that it is not forbidden at all. For, according to them, Qur'an only denounces riba in huge amounts. Some others pronounced alcoholic beverages halal, and that the Qur'an did not prohibit such drinks at all. Another group declared that the allegiance to the British colonial rule in India is compulsory on the Muslims according to the Qur'an and Sunnah.27

Mawdudi fought against all fronts using his 'gifted' pen and forceful speeches and dispelled all confusions raised against Islam. He also fought against the false prophethood of Gulam Ahmad Qadiyani by writing a Pamphlet on Qadiyanism and their basic tenets, for which he was 'awarded' death sentence. He did not fear anyone in explaining the ideology of Islam and striving to establish it in Pakistan. The Court brought charge against him that he incited people against Qadiyanis, the citizens of Pakistan, by issuing a statement in the Press. His lawyer advised him to say in the court that it is not necessary that what was published in the newspapers to be his exact words. Mawdudi did not mince the matters. He said openly in the court that he bears full responsibility for every single word of his statement published in the daily newspapers. 28

His writings against anti-Hadith movement remained a valued masterpiece which is used by Muslim scholars throughout the world.29 His books Tafhimat [Elucidations] and Tanqihat [Critical Reviews] 30 are regarded to be the noble references for those who want Islamic responses against the confusions and attacks of anti-Islamic groups.

\section{Distinction between Islamic and Muslim History}

It was a great contribution of Mawdudi that he distinguished between Islamic and Muslim history. He analyzed the history of Islam from the Prophetic period until the 20th Century. He outlined the strengths of the early generation and how and why Islamic civilization flourished; and what are the main causes that led Islamic civilization to gradually collapse.

This could be seen in his much debated book Khilafat wa Mulukiyyat ${ }^{31}$ [Caliphate 


\section{Sayyid Mawdudi's Contribution Towards Islamic Revivalism}

and Monarchy]. He analyzed the golden age of Islam, the period of the Prophet and Khulafa' Rashidun. He mentioned the basic features of Islamic Khilafah and its strengths; and that how it was transformed into monarchy. He observed that during the time of Mu'awiyah ${ }^{\circledR}$ the shift from Khilafah to Mulukiyyah took place, though some minor steps of 'Uthman ${ }^{\circledR}$ could be held responsible for such a shift. This straightforward presentation and plain approach made many Muslims as his deadliest enemies. Traditional scholars waged an intellectual (!) war against him. He was accused, reviled, vilified for mentioning the companions of the Prophet in inappropriate terms. Though Mawdudi furnished all references for every single statement that he made in that book, the traditional scholars took little notice of it. Mawdudi wanted to learn lessons from the mistakes of the past history so that it could shed light in the future history of Islam. But the people generally regarded all the companions of the Prophet as Ma`sum or sinless like the Prophet himself.

Another book, The Revivalist Movement in Islam $^{32}$ also bore criticism from various segments in society. He mentioned briefly the contributions of great Islamic revivalists and explained their methodology. He did not hesitate to analyze their approaches to Islamic reform, its strengths and also setbacks. He dealt with the movement of Sayyid Ahmad Shahid and also Shah Wali Ullah in detail, and mentioned why their movements did not reach worldly success and victory. This caused fury among the Muslim masses in India. They were not ready to hear any criticism against great scholars and reformers of Islam. Mawdudi's approach was not to downplay their role, but to learn from the strengths and weaknesses of the past reformers for the future reform activities.

\section{Attracting people towards the Qur'an}

The famous tafsir of Mawdudi, Tafhim al-Qur'an [The Meaning of the Qur'an] could be regarded as magnum opus among all his writings. Through this Tafsir, he attracted many people especially the young and dynamic generation to the Qur'an. The real message of the Qur'an was neglected by many Commentators who had engaged themselves in the theological, grammatical and scholastic discussions and debates. The Qur'an was revealed as an eternal Book of guidance to humanity. The Qur'an has been used for all other motives except deriving hidayah from it. The Orientalists and anti-Islamic writers focused fierce criticism against the Qur'an and the Prophet Muhammad. This made many modern Muslims confused about their religion and the holy Book.

Mawdudi wrote this Tafsir for the dynamic and modern educated people who have little or no knowledge of Arabic. Therefore, we find him very precise and brief in his first and second volumes of Tafhim al-Qur'an. But later he changed his style in remaining four volumes and explained the ayat and the issues of the Qur'an in detail. The style he adopted was plain and forceful presentation of the message of the Qur'an in clear Urdu language. He cautiously avoided the literal translation of the Qur'an and skillfully presented the message of the Qur'an in plain and forceful language. He says in the first volume of his tafsir:

"The objective of this book is to present the basic meaning and message of the Qur'an to the modern educated class, who have little access to the Arabic language; so that they could get the same impression that the Qur'an wants to deliver. I also tried to dispel all doubts and confusions that may arise in their minds during the study of the Qur'an."33

Mawdudi's main objective in his Tafsir was to present the Qur'an as a Book of 


\section{IIUC Studies, Vol. 3}

eternal guidance. His Tafsir possesses encyclopedic information in various fields of knowledge, but never was diverted from the real message of the Qur'an, i.e. to present it as a Book of guidance. His Tafsir has hardly any parallel in the Urdu language. He transformed the message of the Qur'an from clear, plain and forceful Arabic to a plain and forceful Urdu language. An objective reader of his Tafsir is likely to be influenced by this Tafsir. ${ }^{34}$

The chief characteristic of this Tafsir lies in presenting the meaning and message of the Qur'an in a language and style that penetrates the hearts and minds of the men and women of today and shows the relevance of the Qur'an to their everyday problems, both on the individual and societal planes. ${ }^{35}$

His Tafsir played a significant impact on the hearts and minds of modern educated youths of Pakistan and through its translation even abroad. Previously, the people read the Qur'an for barakah and blessings. Mawdudi was able to change this attitude of the people and made them to read it for understanding and implementation. The educated generation loved the Qur'an, as they could understand it wonderfully through the great work of Mawdudi. They found that the Qur'an solves modern problems and is fully relevant in today's realities as it was relevant in the time of the Prophet.

The impact of his Tafsir and a glance of Mawdudi's character could be found in the following incident that an ordinary tailor from Karachi was sentenced to death in a family dispute and was counting his last days of life in the central jail of Karachi. Once he wrote a letter to Sayyid Mawdudi requesting him to send a volume of Tafsir to him. On exactly the 10th day after sending the letter, he received a copy of Tafhim with the signature of Mawdudi and a brief letter. Later his sentence was commuted to life imprisonment. Then he decided to arrange dars-i-Qur'an [lesson from the Qur'an] in the prison and started delivering dars-i-Qur'an inside the prison. All 72 prisoners in the prison started participating in the dars after making wudu [ablution] and wearing clean clothes. ${ }^{36}$ This incident shows the far-reaching impact of Mawdudi and his Tafsir that even the prisoners of jail, majority of whom were caught for grave crimes and offenses, were not beyond its reach.

Mawdudi advises that if one wants to get lessons from the Qur'an, he should free himself from all pre-conceived notions and prejudices. He should not read the Qur'an from sectarian perspective. If he remained preoccupied with his own notions, he would only read his own ideas in the pages of the Qur'an. He also advises that the lessons from the Qur'an could never be achieved through arm-chair studies; it requires one to actively participate in the mission of the Qur'an. He should face all challenges as the Prophet Muhammad faced during his life. He could then taste the Qur'an properly and find the Qur'an addressing his own situations and problems. ${ }^{37}$

\section{Building Character}

He built his own character on Prophetic model and tried whole of his life to mould others' characters as well in the same direction. The life example of the Prophet, peace be upon him, was the only model that he emulated and urged others to emulate. In doing so, he had to offer great sacrifices and face tortures and jails by ruling dictators. He was a symbol of courage, truthfulness, straightforwardness and simplicity. He never tried to mince matters. He always spoke a spade a spade. He raised his self-esteem so high that never allowed his head to bow before any tyrants, nor did he seek any advantage for his own person from them. His truthfulness sometimes caused him to face grave dangers even to face death sentence. He was 


\section{Sayyid Mawdudi's Contribution Towards Islamic Revivalism}

ready to accept death sentence happily than to offer an appeal of apology to them. After writing a book on Qadiyanism and issuing a press statement he was tried in Marshal Court and sentenced to death. Later he was given green signal that he would be released if he submits an appeal to the ruling authority. Mawdudi rejected it outright and said:

"The decision of life and death is taken in the heavens and not on the earth. If my death was decided by Allah, no power in the world could protect me. But if He did not yet decide death for me, no one in the world could do any harm to me." ${ }^{38}$

He worked whole of his life for the Sovereignty of Allah and to eliminate lordship of humans over others. His Iman in Allah was firm like mountains. His sole objective was to attain the Pleasure of Allah and forgiveness from Him. He did not allow himself to use harsh language against others' severe criticism. His life was full of forgiveness and love for others. The Judge who decreed his death sentence came once to meet him. Mawdudi's heart was warm and welcoming for friends and foes. He offered the Judge a very warmth and cordial reception that he was deeply touched by the nobility of his character. ${ }^{39}$

\section{Influence Worldwide}

He was not the leader of the Muslims in Pakistan alone, but was in fact a leader of the world's Muslims. The Muslims remember him in great reverence. His books have been widely translated throughout the world. ${ }^{40}$ The seminars and conferences on Islam cite his books as reference in high terms. Ph.D. and Masters dissertations are written on his life, thought and books throughout the world. Many books are being written on him throughout the globe from Muslims and non-Muslims alike. This is a clear reflection that Muslims of today need guidance and lessons from the life and mission of Mawdudi.

His thought has influenced many educated ones especially the youth. They found in him the person of their expectation, the symbol of courage and determination, a true realization of word and deed, an ocean of knowledge, a devoted personality for the cause of Islam and capable of dealing with the present issues in the light of the Qur'an and Sunnah. His magnum opus Tafhim al-Qur'an played an important role in captivating the hearts of the youth.

The movement of Jama 'at-i-Islami that he established in 1941, is not confined now in Pakistan alone. Its activities reached the last part of the globe. Its literatures were widely circulated in many international languages. Jama at-i-Islami is accepted as a moderate Islamic movement of the 20th century. Mawdudi did not resort to violence in his whole lifetime. He resisted the violence of anti-Islamic groups with wisdom, patience and forgiveness. He did not allow his companions to be aggressive on others. Therefore, Jama at-i-Islami could work peacefully in many countries of the world.

\section{Conclusion}

Sayyid Abul-A'la Mawdudi lived for about 76 years, and devoted his life for the cause and promotion of Islam and its revival in the present-day-world. The Muslims of the 20th Century lost their noble identity, self-respect and dignity; and surrendered to the Western materialism and secularism. Sayyid Mawdudi played active role in cultivating the feeling of self-respect and dignity among the Muslims. He did not 


\section{IIUC Studies, Vol. 3}

adopt the apologetic stance towards the West.

Cantwell Smith, in his book Islam in modern history, evaluates the contribution of Mawdudi in the following:

The most significant contribution of Maulana Maududi has been the gradual and continual elaboration of an impressive system of ideas. He is the most systematic thinker of modern Islam. It is because of the impact of Maulana Maududi that even those who have differed from him have come increasingly to premise that there is an Islamic system of economics, an Islamic political system, an Islamic Constitution and so on. ${ }^{41}$

A person could disagree with many of his ideas with sound reasoning and proofs; but it should not exceed the limit of decency and moderation. He always kept silent and resorted to Allah in the face of all criticisms. He was rarely seen to be influenced or agitated by such criticisms. He always appreciated constructive remarks and had in fact changed or modified some of his writings by the suggestions of some critics.

May Allah forgive his shortcomings, as no one apart from the Prophets is free from errors, and rest his soul in the Highest Place in Jannah.

\section{Reference}

1. To have an account of criticisms and charges on Mawdudi, see the following: Zakariya, Shaykh al-hadith (1983), Fitanh-i-Mawdudiyyat [Heresy of Mawdudism], India, Saharanpur: Isha'at al-'ulum.

2. See Ahmad, Khurshid and Ansari, Zafar Ishaq (1399/1979), ed. Islamic Perspective. U.K. The Islamic Foundation, p. 9-10.

3. Hassan, Masudul (1984), Sayyid Abul A`ala Maududi and His Thought, Lahore: Islamic Publications Ltd. 1st edition, vol. 2, p. 486-487.

4. Islamic Perspective, p. 5-6

5. Hasan, Masudul, p. 22-23.

6. $\quad$ Ibid. p. 27

7. 'Abd, Chowdhuri Abdur Rahman (1988), Sayyid Abul A la Mawdudi (in Urdu), Islamic Publications Ltd. (IPL), p. 70-71.

8. $\quad$ Ibid. p. 81.

9. Hasan, Masudul, vol. 1, p. 244.

10. Ibid. p. 446.

11. Gilani, Syed Asad 1984, Maududi: Thought and Movement, Lahore: IPL (Islamic Publications Ltd.), p. 401.

12. Ibid. p. 405-406.

13. Sawlat (1979), Sarwar Mawlana Mawdudi. Pakistan: International Islamic Publishers, p. 158160, also in Masud: 2/479-485.

14. See Mawdudi (1996), Islami Nizam-i-Zindagi awr us ke Bunyadi Tasawwrat [Islamic Way of Life and its Basic Cocepts]. Lahore: IPL. 


\section{Sayyid Mawdudi's Contribution Towards Islamic Revivalism}

15. See Mawdudi (1996), Sayyid Abul A 'la, Islami Riyasat (Islamic State), Lahore: IPL, 18th ed. p. 1291-36.

16. Surah Al-Baqarah 2: 85.

17. Qurayshi, Altaf Hassan (1991), Piyare Mawlana, [Beloved Mawlana], Lahore: Jasarat Printers, p. 15-16.

18. 'Abd, Chowdhry Abdur Rahman, Sayyid Abul A'la Mawdudi. pp. 254-255.

19. See Mawdudi (1990), Islamic Law and Constitution, translated and edited by Ahmad, Khurshid, IPL, 10th ed. pp. 253-262. Also see Maulana Maududi and his thought, vol. 2, p.504-505.

20. Mawdudi, Islami Riyasat, p.582-595.

21. Hasan, Masudul, 2/500.

22. Ibid. p. 2/500-502.

23. Ibid. $2 / 513$.

24. See Mawdudi (1990), Al-Jihad fi al-Islam. Lahore: Idarah Tarjuman-ul-Qur'an, p. 21-52.

25. Translated in English as The Status of Women in Islam. [Al-Hijab]; published by Lahore: Islamic Publications Ltd., (1997).

26. See for details, Mawdudi (1996), Purdah (Veil), Lahore: IPL, 47th ed. p. 220-226.

27. Qurayshi, p. 25.

28. Qurayshi,p. 30.

29. See his book (1996). Sunnat ki 'Ayini Haythiyat [Constitutional status of Sunnah]. IPL, 17th edition.

30. Translated in English as Islam Vs. West, and by 1996, 31st edition of the book was published by Islamic publications Ltd. Tafhimat, 4 volumes were also published by IPL, Lahore, Pakistan.

31. Khilafat wa Mulukiyyat [Caliphate and monarchy] (1996), Lahore: Idarah-i-Tarjuman-ulQur'an, 24th edition.

32. Tajdid wa Ihya'-i-Din [Revivalist Movement of Islam] (1995). IPL.

33. Mawdudi (1991), Tafhim al-Qur'an [Meaning of the Qur'an], vol. 1, p. 6, Lahore: Tarjuman al-Qur'an, 12th edition.

34. Khan (1994), "Abbas Ali, "Mawlana Mawdudi: an Encyclopedia of Knowledge" in Zaman, Greatest Da i of the Century [in Bengali]. Dhaka: Adhunik Prakashani, p. 264-265.

35. Islamic Perspective, p. 9-10.

36. Ibid.

37. Tafhim, 1/33-34.

38. Gilani, Syed Asad, Maududi: Thought and Movement, p. 131.

39. Qurayshi, p. 48.

40. It is reported that his book Towards Understanding Islam has been translated by 1974 in 26 languages of the world, and by November 1967, 26 editions of this book have already been published in Urdu alone. It was a book that he wrote in his 30s, and completed it surprisingly within a few weeks. See Sawlat, Sarwar, p. 5; also in Hamidi, Khalil. Al-Imam Abul A la al- 
IIUC Studies, Vol. 3

Mawdudi: Hayatuhu, Da`watuhu wa Jihaduhu [Abul A`la Mawdudi: his life, mission and movement]. Lahore: Dar al-'Arubah, (1410AH/1989AC), pp. 25-26.

41. Smith, Cantwell (1977), Islam in Modern History, New Jersey: Princeton University Press, p. 235. 